Brit. J. industr. Med., 1964, 21, 197.

\title{
DISTRIBUTION AND EXCRETION OF METHYL AND PHENYL MERCURY SALTS
}

\author{
BY \\ J. C. GAGE \\ From Imperial Chemical Industries Ltd., \\ Industrial Hygiene Research Laboratories, Alderley Park, Macclesfield, Cheshire
}

(RECEIVFD FOR PUBLICATION NOVEMBER 29, 1962)

\begin{abstract}
The distribution, metabolism, and excretion of phenyl mercury acetate (P.M.A.) and of methyl mercury dicyanidiamide (M.M.D.) has been studied in the rat during the repeated subcutaneous administration of small doses over a period of six weeks, and for several weeks after a single dose.

The results indicate that P.M.A. is absorbed unchanged into the circulation from which it is mainly removed by the liver and kidneys where it is metabolized and excreted in the faeces and urine mostly as inorganic mercury. During repeated dosage the rats reached a steady state by the end of the second week when excretion approximately balanced intake. No measurable amount of mercury was found in the central nervous system.

After repeated dosage with M.M.D. there is no clear indication of a steady state being reached after six weeks. There is an accumulation of organic mercury in all tissues, particularly in the red cells, and a progressive increase in the brain concentration. M.M.D. is more slowly released from the tissues than P.M.A. and the breakdown to inorganic mercury is low.

The control of human exposure to alkyl and aryl mercury salts is considered in the light of these experimental observations. The recommendation that the concentration of alkyl mercury salts in the atmosphere should not exceed $0.01 \mathrm{mg} . / \mathrm{m}^{3}$ seems justifiable, but there appears to be no reason to establish the figure for aryl mercury salts below the $0.1 \mathrm{mg} . / \mathrm{m}^{3}$ recommended for inorganic mercury vapour.
\end{abstract}

Organic mercury salts have been employed for many years as fungicides in agriculture and in the paper industry. Phenyl mercury acetate (P.M.A.) is most widely used for the prevention of slime formation in paper and in the formulation of seed dressings; for the latter purpose it is often combined with a small proportion of alkyl mercury salts. In recent years there has been a tendency in some countries to replace P.M.A. by methyl mercury dicyanidiamide (M.M.D.) on account of certain technical advantages.

There are no recorded cases of poisoning from the industrial or agricultural use of P.M.A., apart from a local action on the skin. It is widely held that the alkyl mercury salts are more toxic than P.M.A. on account of numerous cases of injury, characterized by muscular weakness leading to irreversible paralysis and death, which have been attributed to their use (Ahlmark, 1948; Swensson, Lundgren, and Lindström, 1959a). There has been some confusion in the literature concerning the relative toxicities of alkyl and aryl mercury salts to animals, probably due to the observations that the median lethal doses of both are of the same order (Swensson, 1952). It is, however, quite certain that only the alkyl mercury salts give rise to the characteristic neurotoxic effects which develop in the survivors of the median lethal dose or in animals receiving a series of sub-lethal doses (Gage and Swan, 1961).

There have been several attempts to correlate this difference in toxicity with the metabolic fate of these two chemical types. It has been shown that the distribution of mercury after a single dose of P.M.A. administered by various routes resembles in the main that produced by inorganic mercury, most being found in the kidneys with none in the brain (Swensson et al., 1959a; Prickett, Laug, and Kunze, 1950; Friberg, Odeblad, and Forssman, 1957). Swensson et al. (1959a) found a more uniform distribution of mercury in the tissues after a single intravenous dose of M.M.D., but none could be detected in the brain. After repeated administration 
of M.M.D. Friberg (1959) found that mercury was more firmly held by the tissues than after P.M.A. administration and that an appreciable amount of mercury entered the brain. Swensson, Lundgren, and Lindström (1959b) found mercury in the brain after repeated administration of both M.M.D. and P.M.A. and claimed that the concentration was proportional to the concentration in the blood.

In the above experiments no attempt was made to distinguish between organic and inorganic mercury in the tissues. Differential analyses have been made by Miller and his colleagues (Miller, Klavano, and Csonka, 1960; Miller, Klavano, Jerstad, and Csonka, 1961) in their study of the fate of P.M.A. and ethyl mercury chloride after single intramuscular doses. They deduced from these experiments that both are transferred unchanged into the circulation and that P.M.A. is metabolized by the liver and kidneys to liberate inorganic mercury, while ethyl mercury chloride is only very slowly eliminated and is more resistant to degradation.

Although the published information is sufficient to indicate that the greater toxicity of alkyl mercury salts may be connected with their persistence in the blood stream and their ability to enter the tissues including the brain, the results cannot readily be applied to the surveillance of workers exposed to aryl and alkyl mercury salts in industry and agriculture. In the investigation described below, which has been briefly reported elsewhere (Gage and Swan, 1961), an attempt has been made to study the progressive accumulation and degradation of M.M.D. and P.M.A. in the rat after prolonged absorption of small doses, and thereby to predict the value of tests in man of blood and excreta to detect excessive exposure.

\section{Analytical Methods}

The organic materials used in this investigation were M.M.D. and P.M.A. Both were colourless crystalline solids which were found to contain, by the method for total mercury referred to below, 56 and $68 \%$ mercury respectively, which is about $95 \%$ of the theoretical figure.

Organic mercury was determined in the tissues and faeces by extracting an acidified homogenate with benzene and re-extracting the benzene layer with aqueous sodium sulphide. The sodium sulphide extract was oxidized with acid-permanganate and the mercury content determined by a titrimetric dithizone procedure (Gage, 1961a). Undiluted urine was similarly treated. The recovery of known amounts of M.M.D. and P.M.A. added to liver, kidneys, brain, spleen, muscle, lungs, faeces, and urine is shown in Table 1. The determination of
TABLE 1

RECOVERY OF M.M.D. AND P.M.A. FROM RAT TISSUES AND EXCRETA

\begin{tabular}{l|c|c|c|c}
\hline \multirow{2}{*}{} & \multicolumn{2}{|c}{$\%$ Recovery of Added M.M.D. and P.M.A. } \\
\cline { 2 - 3 } \cline { 5 - 5 } & \multicolumn{2}{|c}{ M.M.D. } & \multicolumn{2}{c}{ P.M.A. } \\
\cline { 2 - 3 } & $1 \mathrm{ppm}$ & $5 \mathrm{ppm}$ & $1 \mathrm{ppm}$ & $5 \mathrm{ppm}$ \\
\hline Liver & 100,96 & 98,99 & 94,98 & 100,98 \\
Kidneys & 96,98 & 98,99 & 106,99 & 100,94 \\
Brain & 101,101 & 100,102 & 94,99 & 96,102 \\
Spleen & 100,102 & 96,99 & 99,99 & 96,100 \\
Muscle & 95,98 & 98,98 & 102,98 & 96,96 \\
Lung & 99,101 & 100,100 & 99,98 & 98,100 \\
Faeces & 96,98 & 98,99 & 93,98 & 96,94 \\
Urine & 101,102 & 100,100 & 97,95 & 96,99 \\
\hline
\end{tabular}

Homogenates containing $1 \mathrm{~g}$. normal tissues and faeces were analysed with and without the addition of M.M.D. and P.M.A.; $10 \mathrm{ml}$ normal urine was analysed undiluted. Recoveries were determined in duplicate at M.M.D. and P.M.A. concentrations of 1 and 5 ppm.

organic mercury in fat and hair was less satisfactory, and for these only the total mercury content is reported.

Total mercury was determined by dithizone titration after oxidation with acid-permanganate (Gage, 1961b). This method gives satisfactory recoveries from tissues and excreta with the exception of faeces and fat. With faeces the recoveries were variable and rather low, in the region of $80 \%$, and attempts to measure concentrations less than $1 \mathrm{ppm}$ may be subject to serious error. The relatively mild oxidizing conditions used were insufficient to destroy the organic matter in fat unless the amount of sample was reduced to $0.1 \mathrm{~g}$. and the oxidizing period extended to 18 hours; under these conditions recoveries of $90 \%$ or better were obtained.

The duplicate recovery experiments in Table 1 permit a calculation of the reproducibility of the method. The results give no clear indication that the overall variation is not homogeneous, and the standard deviation is therefore given by the expression $\sqrt{ } \Sigma w^{2} / k$, where $k$ is the number of duplicates and $w$ is the difference between each pair. The coefficient of variation of tests on a single sample is $1.35 \%$ for M.M.D. and $2.75 \%$ for P.M.A. A similar calculation based on the differences between the means at 1 and $5 \mathrm{ppm}$ indicates that no further significant error is introduced by analysing different samples. The previously published recoveries of inorganic mercury from tissues (Gage, 1961b) indicate that the coefficient of variation for total mercury is $2 \cdot 1 \%$.

The bulked tissues and faeces were homogenized in water, and an amount equivalent to $0.5 \mathrm{~g}$. was taken for total mercury content and $1.0 \mathrm{~g}$. for organic mercury. For low concentrations a larger amount was taken if available. The lower limit of mercury that can reliably be measured is $0.5 \mu \mathrm{g}$.; 
below this the results are uncertain. Where less than this amount was found, the results have been reported as less than a figure based on $0.5 \mu \mathrm{g}$. in the weight of sample taken for analysis. For urine, $10 \mathrm{ml}$. pooled urine was taken.

\section{Animal Experiments}

A group of 40 female albino Wistar rats, $125-135 \mathrm{~g}$. body weight, were injected subcutaneously three times a week for six weeks with an aqueous solution of M.M.D., and another group was similarly dosed with P.M.A. In both groups the individual doses were equivalent to $0 \cdot 15 \mathrm{mg}$. mercury per rat. No toxic effects were produced, and at the end of the six-week period the weight range was 170 to $190 \mathrm{~g}$. At the commencement of the series of injections five rats from each group were placed in a metabolism cage provided with a separator for urine and faeces of a type previously described (Gage, 1961b); the excreta of these rats were collected for one week and then the animals were killed and the liver, kidneys, brain and cord, spleen, and an area of shaved skin from the injection site were taken for organic and total mercury analysis. Another sample of five rats from each group was similarly treated during the second week of the experiment, and this weekly sampling was continued throughout the six weeks. A more complete tissue analysis was made from the final group.

Two further groups of five rats received single subcutaneous doses of M.M.D. and P.M.A., equivalent to $0.5 \mathrm{mg}$. mercury per rat, and the excreta were collected and analysed over a period of three weeks.

\section{Experimental Results}

The organic and total mercury content of the tissues and excreta shown in Tables 2 and 3 give an indication of the accumulation and excretion of mercury during the six-week experiment. In the M.M.D. rats there is an indication of a progressive increase in the tissue concentrations throughout the period, and only about one-quarter of the $0.45 \mathrm{mg}$. mercury administered weekly appears in the excreta. A precise balance-sheet at the end of the period cannot be made as the total amounts in muscle,

TABLE 2

ORGANIC AND TOTAL MERCURY CONTENT OF RATS DOSED WITH THE EQUIVALENT OF 0.45 mg. MERCURY PER WEEK

\begin{tabular}{|c|c|c|c|c|c|c|c|c|c|c|c|c|c|c|c|}
\hline & & \multicolumn{7}{|c|}{ Methyl Mercury Dicyanidiamide } & \multicolumn{7}{|c|}{ Phenyl Mercury Acetate } \\
\hline & & 1 & 2 & 3 & 4 & 5 & & 5 & 1 & 2 & 3 & 4 & 5 & & 6 \\
\hline Kidney: & $\begin{array}{l}\text { organic } \\
\text { total }\end{array}$ & $\begin{array}{r}13 \\
9\end{array}$ & $\begin{array}{l}20 \\
32\end{array}$ & $\begin{array}{l}32 \\
45\end{array}$ & $\begin{array}{l}42 \\
65\end{array}$ & $\begin{array}{l}42 \\
73\end{array}$ & $\begin{array}{l}30 \\
54\end{array}$ & $\begin{array}{c}(\mu \mathrm{g} . / \mathrm{g} .) \\
28 \\
51\end{array}$ & $\begin{array}{r}3 \\
96\end{array}$ & $\begin{array}{l}1.5 \\
93\end{array}$ & $\begin{array}{r}2 \\
110\end{array}$ & 91 & 117 & 117 & $\begin{array}{c}(\mu \mathrm{g} . / \mathrm{g} .) \\
2 \\
90\end{array}$ \\
\hline Liver: & $\begin{array}{l}\text { organic } \\
\text { total }\end{array}$ & $\frac{22}{27}$ & $\begin{array}{l}37 \\
39\end{array}$ & $\begin{array}{l}45 \\
54\end{array}$ & $\begin{array}{l}46 \\
53\end{array}$ & $\begin{array}{l}54 \\
64\end{array}$ & $\begin{array}{l}81 \\
81\end{array}$ & $\begin{array}{l}16 \\
16\end{array}$ & $\begin{array}{c}<2 \cdot 5 \\
15\end{array}$ & $\begin{array}{c}<2.5 \\
10\end{array}$ & $\begin{array}{c}<2.5 \\
20\end{array}$ & $\begin{array}{c}<2.5 \\
12\end{array}$ & 20 & $<1$ & $\begin{array}{r}<0.2 \\
1.3\end{array}$ \\
\hline Brain and cord: & $\begin{array}{l}\text { organic } \\
\text { total }\end{array}$ & $\begin{array}{l}<1 \\
<2\end{array}$ & $\begin{array}{r}3 \\
<2\end{array}$ & $\begin{array}{r}3 \\
<2\end{array}$ & $\begin{array}{r}4 \\
<2 \\
\end{array}$ & $\begin{array}{l}4 \\
2\end{array}$ & $\begin{array}{l}7 \\
8\end{array}$ & $\begin{array}{l}3 \\
4\end{array}$ & $\begin{array}{l}<1 \\
<2\end{array}$ & $\begin{array}{l}<1 \\
<2\end{array}$ & $\begin{array}{l}<1 \\
<2\end{array}$ & $\begin{array}{l}<1 \\
<2\end{array}$ & $\begin{array}{l}<1 \\
<2\end{array}$ & $\begin{array}{l}<1 \\
<2\end{array}$ & $\begin{array}{l}<0.5 \\
<1\end{array}$ \\
\hline Spleen: & $\begin{array}{l}\text { organic } \\
\text { total }\end{array}$ & $\begin{array}{l}5 \\
5\end{array}$ & $\begin{array}{l}15 \\
15\end{array}$ & $\begin{array}{l}19 \\
17\end{array}$ & $\begin{array}{l}25 \\
29\end{array}$ & $\begin{array}{l}19 \\
21\end{array}$ & $\begin{array}{l}22 \\
25\end{array}$ & $\begin{array}{l}27 \\
30\end{array}$ & $\begin{array}{l}<0.4 \\
<0.6\end{array}$ & $\begin{array}{r}<0.4 \\
0.6\end{array}$ & $\begin{array}{l}<0 \cdot 5 \\
<1\end{array}$ & $\begin{array}{l}<0.5 \\
<0.8\end{array}$ & $\begin{array}{l}<0.8 \\
<1.5\end{array}$ & $\begin{array}{l}<0 \cdot 6 \\
<1\end{array}$ & $\begin{array}{l}<0.5 \\
<1\end{array}$ \\
\hline $\begin{array}{l}\text { Skin (injection } \\
\text { site) }\end{array}$ & $\begin{array}{l}\text { organic } \\
\text { total }\end{array}$ & $\begin{array}{l}17 \\
21\end{array}$ & $\begin{array}{l}20 \\
33\end{array}$ & $\begin{array}{l}21 \\
27\end{array}$ & 11 & $\begin{array}{l}7 \cdot 5 \\
7 \cdot 5\end{array}$ & $\begin{array}{l}13 \\
32\end{array}$ & $\begin{array}{l}1 \cdot 5 \\
4\end{array}$ & $\begin{array}{l}10 \\
18\end{array}$ & $\begin{array}{l}11 \\
25\end{array}$ & $\begin{array}{l}13 \\
36\end{array}$ & $\begin{array}{r}7 \\
15\end{array}$ & $\begin{array}{l}1.5 \\
1.5\end{array}$ & $2 \cdot 5$ & $\begin{array}{l}0.4 \\
2\end{array}$ \\
\hline Muscle: & $\begin{array}{l}\text { organic } \\
\text { total }\end{array}$ & & & & & & $\begin{array}{r}82 \\
260\end{array}$ & $\frac{1}{2 \cdot 6}$ & & & & & & $\begin{array}{l}103 \\
232\end{array}$ & $3^{1 \cdot 3}$ \\
\hline Red cells: & $\begin{array}{l}\text { organic } \\
\text { total }\end{array}$ & & & & & & $\begin{array}{l}432 \\
480\end{array}$ & $\begin{array}{l}72 \\
80\end{array}$ & & & & & & $\begin{array}{l}4 \\
6\end{array}$ & $\begin{array}{l}0 \cdot 7 \\
1\end{array}$ \\
\hline Blood plasma: & $\begin{array}{l}\text { organic } \\
\text { total }\end{array}$ & & & & & & $\begin{array}{l}16 \\
22\end{array}$ & $\begin{array}{l}2.7 \\
3.6\end{array}$ & & & & & & 1 & $\begin{array}{l}0 \cdot 2 \\
0 \cdot 2\end{array}$ \\
\hline Intestine: & $\begin{array}{l}\text { organic } \\
\text { total }\end{array}$ & & & & & & $\begin{array}{l}27 \\
65\end{array}$ & $\begin{array}{l}2 \cdot 7 \\
6 \cdot 5\end{array}$ & & & & & & $\begin{array}{l}<5 \\
<10\end{array}$ & $\begin{array}{l}<0.5 \\
<1\end{array}$ \\
\hline Heart muscle: & $\begin{array}{l}\text { organic } \\
\text { total }\end{array}$ & & & & & & $\begin{array}{r}9 \\
10\end{array}$ & $\begin{array}{l}17 \cdot 3 \\
19 \cdot 5\end{array}$ & & & & & & $\begin{array}{l}<0.3 \\
<0.6\end{array}$ & $\begin{array}{l}<0 \cdot 5 \\
<1\end{array}$ \\
\hline Hair: & $\begin{array}{l}\text { dorsal } \\
\text { ventral }\end{array}$ & & & & & & & $\begin{array}{l}215 \\
110\end{array}$ & & & & & & & $\begin{array}{l}28 \\
14\end{array}$ \\
\hline Body fat & & & & & & & & $<5$ & & & & & & & $<5$ \\
\hline
\end{tabular}

Figures are $\mu \mathrm{g}$. mercury per rat and are the average of six rats taken at weekly intervals. The second column of the last group shows the caculation in $\mu \mathrm{g} . / \mathrm{g}$. tissue.

The content of blood and muscle is estimated from the assumptions that each rat contained 10 ml. blood and that the skeletal muscle constituted $43 \%$ of the body weight. 
TABLE 3

WEEKLY ORGANIC AND TOTAL MERCURY EXCRETION BY RATS DOSED WITH THE EQUIVALENT OF 0.45 Mg. MERCURY PER WEEK FOR SIX WEEKS

\begin{tabular}{|c|c|c|c|c|c|c|c|c|c|c|c|c|c|}
\hline & & \multicolumn{6}{|c|}{ Methyl Mercury Dicyanidiamide } & \multicolumn{6}{|c|}{ Phenyl Mercury Acetate } \\
\hline & & 1 & 2 & 3 & 4 & 5 & 6 & 1 & 2 & 3 & 4 & 5 & 6 \\
\hline Urine: & $\begin{array}{l}\text { organic } \\
\text { total }\end{array}$ & $\begin{array}{l}5 \\
6\end{array}$ & $\begin{array}{r}7 \\
10\end{array}$ & $\begin{array}{l}20 \\
22\end{array}$ & $\begin{array}{l}24 \\
30\end{array}$ & $\begin{array}{l}31 \\
41\end{array}$ & $\begin{array}{l}38 \\
42\end{array}$ & $\begin{array}{r}7 \\
44\end{array}$ & $\begin{array}{l}16 \\
89\end{array}$ & $\begin{array}{l}10 \\
85\end{array}$ & $\begin{array}{l}25 \\
99\end{array}$ & $\begin{array}{r}13 \\
106\end{array}$ & $\begin{array}{r}7 \\
102\end{array}$ \\
\hline Faeces: & $\begin{array}{l}\text { organic } \\
\text { total }\end{array}$ & $\begin{array}{l}<14 \\
<30\end{array}$ & $\begin{array}{r}21 \\
<30\end{array}$ & $\begin{array}{r}70 \\
145\end{array}$ & $\begin{array}{l}41 \\
81\end{array}$ & $\begin{array}{r}41 \\
127\end{array}$ & $\begin{array}{l}35 \\
67\end{array}$ & $\begin{array}{r}<18 \\
159\end{array}$ & $\begin{array}{l}<17 \\
185\end{array}$ & $\begin{array}{r}21 \\
182\end{array}$ & $\begin{array}{r}20 \\
116\end{array}$ & $\begin{array}{l}<12 \\
185\end{array}$ & $\begin{array}{l}<10 \\
148\end{array}$ \\
\hline \multicolumn{2}{|c|}{ Total in excreta } & $<36$ & $<40$ & 167 & 111 & 168 & 109 & 203 & 274 & 267 & 215 & 291 & 250 \\
\hline
\end{tabular}

Figures are $\mu \mathrm{g}$. mercury per rat per week and are the average of a group of six rats.

TABLE 4

EXCRETION OF ORGANIC AND TOTAL MERCURY AFTER A SINGLE SUBCUTANEOUS DOSE EQUIVALENT TO $1 \mathrm{mg} . / \mathrm{kg}$. MERCURY

\begin{tabular}{|c|c|c|c|c|c|c|c|c|c|}
\hline & \multirow{3}{*}{ · } & \multicolumn{4}{|c|}{ Methyl Mercury Dicyanidiamide } & \multicolumn{4}{|c|}{ Phenyl Mercury Acetate } \\
\hline & & \multicolumn{2}{|c|}{ Urine } & \multicolumn{2}{|c|}{ Faeces } & \multicolumn{2}{|c|}{ Urine } & \multicolumn{2}{|c|}{ Faeces } \\
\hline & & Organic & Total & Organic & Total & Organic & Total & Organic & Total \\
\hline $\begin{array}{lr}\text { First week: day } 1 \\
& 2 \\
& 3 \\
& 4 \\
& 5 \\
& 6 \\
& 7 \\
\text { Second week } & \\
\text { Third week } & \\
\text { Total } & \end{array}$ & & $\begin{array}{r}2.2 \\
4 \\
3 \cdot 6 \\
<0 \cdot 4 \\
<0 \cdot 4 \\
0 \cdot 6 \\
2 \cdot 8 \\
17 \cdot 5 \\
15 \cdot 5\end{array}$ & $\begin{array}{l}2 \cdot 1 \\
3 \cdot 7 \\
3 \cdot 6 \\
2 \\
3 \cdot 6 \\
3 \\
2 \cdot 2 \\
17 \\
18 \\
55\end{array}$ & $\begin{array}{r}4 \cdot 2 \\
7 \cdot 1 \\
10 \cdot 5 \\
<4 \\
<3 \cdot 5 \\
6 \cdot 5 \\
3 \cdot 5 \\
21 \cdot 6 \\
10\end{array}$ & $\begin{array}{c}7 \cdot 5 \\
12 \cdot 5 \\
18 \\
13 \cdot 5 \\
18 \\
<4 \\
6 \cdot 5 \\
50 \\
24 \\
150\end{array}$ & $\begin{array}{c}22 \\
2.6 \\
0.8 \\
<0.4 \\
<0.2 \\
2.1 \\
0.3 \\
4 \\
-\end{array}$ & $\begin{array}{l}22 \\
6 \\
16 \\
23 \\
10 \cdot 5 \\
10 \\
10 \cdot 5 \\
26 \\
<3 \\
124\end{array}$ & 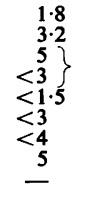 & $\begin{array}{r}17 \\
106 \\
229 \\
54 \\
38 \\
43 \\
75 \\
<5 \\
552\end{array}$ \\
\hline
\end{tabular}

Figures are $\mu \mathrm{g}$. mercury per rat and are averages of five rats.

blood, and hair cannot be calculated with enough accuracy, but it seems likely that at least two-thirds of the dose administered can be found in the tissues and excreta. With P.M.A. the concentration in the tissues appeared to reach a steady state by the end of the second week, and the weekly excretion was fairly constant at about three-fifths of the weekly dose. As most of this excretion was in the faeces, where the determination of low total mercury concentrations is known to give somewhat variable results, it is possible that this deficit is due to analytical error.

The excretion after single doses of M.M.D. and P.M.A. is shown in Table 4. On the day after dosing, the P.M.A. rats excreted organic mercury in the urine, and this rapidly diminished to very low values. Inorganic mercury appeared in the urine on the second day and increased to a maximum by the fourth day and then decreased until at the end of the second week very small amounts were being excreted. About two-thirds of the dose administered could be recovered from the excreta in this experiment. With the M.M.D. rats the organic and inorganic mercury in the urine fluctuated round a low average figure throughout the duration of the experiment. In faeces, the figures were initially higher but progressively decreased to very low values at the end of the experiment. The total mercury recovered was about one-fifth of the dose administered.

\section{Discussion}

P.M.A. is readily absorbed from the injection site, and the low blood concentration indicates that it is rapidly removed by the tissues. Some concentration and probably some metabolism of P.M.A. occurs in skeletal muscle, but the bulk of the P.M.A. is removed from plasma by the liver and the kidneys where it is rapidly metabolized and excreted with only a small proportion appearing unchanged in the faeces and urine. Table 4 shows that, after a single dose, organic mercury is initially excreted in the urine followed by the appearance of inorganic mercury. This delay in organic excretion is greater than would be expected from the results previously obtained when rats were exposed to mercury vapour, and the ratio between the amounts in the urine and in the kidneys is less (Gage, 1961b). These observations suggest that the circulating P.M.A. which enters the kidneys is in part rapidly excreted unchanged in the urine and in part converted to inorganic mercury which is not readily available for excretion. 
In the rats receiving repeated doses of M.M.D., the absorption from the injection site was also rapid, but the blood concentration was high by the end of the experiment, due to an accumulation in the red cells. M.M.D. is taken up by all tissues, and in most the concentration reached is higher than in plasma. There is an indication of a slow release of inorganic mercury in the tissues, particularly in skeletal muscle and intestine. The major route of excretion is through the gut, but the ratio of organic mercury in the liver and faeces indicates that M.M.D. is more slowly excreted from the liver than is P.M.A. The ratio of organic mercury in the urine and kidneys indicates that M.M.D. is also excreted by this route more slowly than P.M.A.: this is confirmed by the single-dose experiment and is in agreement with other published work.

With both M.M.D. and P.M.A. there is a high content of mercury in the hair; with M.M.D. the concentration is greater than in any other tissue, and there may be an appreciable excretion of mercury by this route. There is no evidence whether the mercury is excreted in sebum or incorporated into the hair proteins.

From a toxicological viewpoint, the most important difference between M.M.D. and P.M.A. is seen in the amounts entering the brain; there can be no doubt that the toxic action. of repeated small doses of M.M.D. is due to an accumulation of mercury in this organ. Swensson et al. (1959b) have suggested that this is due mainly to the higher concentration of M.M.D. in the blood, and they found the bloodbrain concentration ratios of the two substances to be of the same order, in the region of 10-20. Their observations were based on the total mercury concentration in whole blood and brain, but it seems more appropriate to use the plasma-brain ratio of organic mercury. From Table 2 it is seen that the M.M.D. concentration in plasma is approximately equal to that in the brain, but this ratio cannot be calculated for P.M.A. as the concentration in the brain was too low to be measured. These results are not in conflict with the hypothesis that the higher concentration of M.M.D. in the brain is due to the sustained higher concentration in the plasma and do not require the postulate that M.M.D. has a greater ease of penetration into the central nervous system.

\section{Control of Exposure to Organic Mercurials}

The concentration of organic mercury in the central nervous system of rats receiving repeated doses of M.M.D. equivalent to $0.45 \mathrm{mg}$. mercury per week approached those observed in experiments in these laboratories where the administration of M.M.D. has led to death. Although in the present series of experiments no toxic effects were observed, it is to be presumed that had the treatment been continued longer the animals would have been affected. In experiments previously reported (Gage, 1961b), in which rats were exposed to an atmosphere containing $1 \mathrm{mg} . / \mathrm{m}^{3}$ mercury vapour for 100 hours per week, where the systemic absorp-

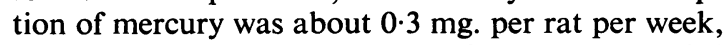
toxic effects were observed after seven weeks' exposure. Experiments of this duration do not indicate that M.M.D. is more toxic than mercury vapour but the very marked accumulation that has been revealed after the prolonged administration of small doses, and the irreversible nature of the lesions produced by M.M.D., suggest that its potential hazard is greater than that of inorganic mercury. In the P.M.A. experiments no toxic effects were observed after treatment with the equivalent of $0.45 \mathrm{mg}$. mercury per rat per week, and no measurable accumulation of mercury was found in the central nervous system; this leads to the conclusion that P.M.A. is less toxic than mercury vapour. The recommended maximal concentration of organic mercury in the atmosphere is $0.01 \mathrm{mg} . / \mathrm{m}^{3}$, that is, one-tenth of the figure for inorganic mercury vapour (Ministry of Labour, 1960). The results of these experiments on the rat suggest that this value is reasonable for alkyl mercury salts, but there is no evidence to support the establishment of a limit for phenyl mercury salts below that widely accepted for inorganic mercury.

This investigation indicates that the determination of mercury in the urine is unlikely to be a useful means of assessing exposure to alkyl and aryl mercury salts. If the fate of P.M.A. in man resembles that in the rat, only about one-eighth of the dose absorbed will be excreted in the urine, and this excretion will continue for more than a week after exposure; urinary mercury determinations are even less likely to be of value than they are during exposure to mercury vapour. With M.M.D. only a very small fraction of the dose absorbed is likely to appear in the urine, and excretion will continue for a long period after exposure. Although measurements of organic mercury in the urine will have some diagnostic value in cases of suspected poisoning it seems unlikely that such measurements would assist in the routine control of exposed workmen, and a limited number of experiments with ethyl mercury chloride have suggested that this will apply to all alkyl mercury salts. The rat experiments have suggested that an analysis of blood might provide a better indication of the absorption of an alkyl mercury salt, but a few tests on rabbits have indicated that the very high concentration observed in the red cells of the rat may not necessarily be 
found in other species. Mercury determinations on hair may be of value in cases of suspected poisoning.

Technical assistance in this investigation was provided by Mr. D. Swanston and Mr. W. P. B. Lyle.

\section{REFERENCES}

AhImark, A. (1948). Brit. J. industr. Med., 5, 117. Friberg, L. (1959). Arch. industr. Health, 20, 42.
Friberg, L., Odeblad, E., and Forssman, S. (1957). Ibid., 16, 163.

Gage, J. C. (1961a). Analyst, 86, 457.

(1961b). Brit. J. industr. Med., 18, 287.

, and Swan, A. A. B. (1961). Biochem. Pharmacol., 8, 77.

Miller, V. L., Klavano, P. A., and Csonka, E. (1960). Toxicol. appl. Pharmacol., 2, 344.

Min , Jerstad, A. C., and Csonka, E. (1961). Ibid., 3, 459. . "Toxic Substances in Factory Atmospheres". Safety, Health and Welfare, New Series, No. 8,

H.M.S.O., London.
Prickett, C. S., Laug, E. P., and Kunze, F. M. (1950). Proc. Soc. exp. Biol. Med., 73, 585 .

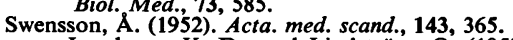

Lundgren, K. D., and Lindström, O. (1959a). Arch. industr. Health, 20, 432.

$-, \ldots$ 